\title{
Galectin Secretion and Modulation in Sheep Blood
}

\author{
Bertha Osei ${ }^{1}$, Mulumebet Worku ${ }^{1}$, Sarah Adjei-Fremah ${ }^{1}$, Emmanuel Asiamah $^{2}$, Kingsley Ekwemalor $^{2}$, \\ Eboghoye ElukaOkoludoh ${ }^{2} \&$ Bharath Mulakala ${ }^{1}$ \\ ${ }^{1}$ Department of Animal Sciences, North Carolina A\&T State University, Greensboro, NC, USA \\ ${ }^{2}$ Department of Applied Science and Technology, North Carolina A\&T State University, Greensboro, NC, USA \\ Correspondence: Mulumebet Worku, Department of Animal Sciences, North Carolina A\&T State University, \\ Greensboro, NC, USA. Email: worku@ncat.edu
}

Received: November 10, 2017

Accepted: November 25, 2018

Online Published: November 30, 2018

doi:10.5539/jmbr.v8n1p183

URL: https://doi.org/10.5539/jmbr.v8n1p183

\begin{abstract}
Galectins (GAL) are $\beta$-galactoside binding proteins that can modulate both pregnancy and the response to pathogens. Increased susceptibility to infection by pathogens is linked to periparturient immune suppression and a periparturient rise (PPR) in parasite eggs on pasture. The possible role of GAL in periparturient immune relaxation and PRR needs definition. The objective of this study was to evaluate galectin secretion and its relationship to measures of the immune relaxation and PRR in periparturient sheep. Samples were collected from pregnant St. Croix sheep $(n=6)$ weekly at days -21 to +21 relative to lambing. Fecal samples were collected and evaluated for strongyle and coccidia parasite eggs. The concentration of $\operatorname{IgA}$ and $\operatorname{IgE}$ coproantibodies, total microbial DNA, Bifidobacteria and Lactobacillus levels in fecal samples were used as indicators of gut health. Blood samples were collected by jugular venipuncture and assessed for Packed Cell Volume (PCV), total and differential white blood cell counts. Total protein concentrations and protein profile were evaluated in serum. Secretion of GAL 1, 3, 9 and 14 were evaluated using ELISAs. Data were analyzed by one-way ANOVA and statistical significance was declared at $P<0.05$. Galectins tested were secreted in sheep blood. Differential modulation of GAL secretion and correlation with periparturient immune suppression and parasite infection was observed. Galectin secretion was modulated by the periparturient period, type and status of parasite infection. This first insight into a possible role of secreted galectins in periparturient immune relaxation and PRR improves the understanding of the immune response, informs development of management programs and therapeutics and presents Galectin profiles as biomarkers with diagnostic potential.
\end{abstract}

Keywords: Galectins, Sheep, Periparturient Period, Bifidobacteria spp, Lactobacillus spp, Coproantibodies, Strongyle, Coccidia. Biomarker

\section{Introduction}

The periparturient period is a critical time for animal health and wellbeing. It is generally the immediate period (3 weeks) before lambing and 3 weeks after lambing. During this time the immune system is relaxed to allow successive coexistence between ewe and lamb (Houdijk, Kyriazakis, Jackson, Huntley, \& Coop, 2000; Than et al., 2012). Periparturient immune suppression and a periparturient rise (PPR) in fecal egg count (Houdijk et al., 2000) results in increased susceptibility to infection by parasites and other pathogens resulting in associated health and welfare concerns. The underlying causes of periparturient relaxation of immunity and the PPR are being reported (Beasley, Kahn, \& Windon, 2010).

Management of disease is becoming increasingly difficult as synthetic anthelmintics and antibiotics are becoming ineffective due to parasite and pathogen resistance worldwide (Asiamah, Adjei-Fremah, Ekwemalor, Sordillo, \& Worku, 2018; Ekwemalor, Adjei-Fremah, Asiamah, \& Worku, 2017; Ekwemalor et al., 2018; Piedrafita, Raadsma, Gonzalez, \& Meeusen, 2010). Breeding ewes are susceptible to negative effects of parasitism in the period immediately before, during and following lambing (Notter, Burke, Miller, \& Morgan, 2017). Understanding the factors that contribute to disease susceptibility during the peripartum period is essential to sustainable animal production. In sheep, the PPR is linked to parasitological, immunological, endocrine and production responses, and their interactions (Beasley et al., 2010). In Merino sheep, changes in circulating cell counts, antibody titer (Beasley et al., 2010) leptin and cortisol concentration were linked with both parasite and immune status of the ewe (Beasley et al., 2010). These authors highlighted the need for the identification of factors 
that contribute to biasing toward a Th1-type immune response. Factors that may influence PPI have been related to genotype (Goldberg, Ciappesoni, \& Aguilar, 2012; Rocha et al., 2011).

Sheep of Caribbean origin have become an important part of a strategy to use breeds that resist infection for the control of parasites (Bishop \& Morris, 2007; Piedrafita et al., 2010). St. Croix sheep are resistant to gastrointestinal nematodes (Courtney, Parker, McClure, \& Herd, 1985; Gamble \& Zajac, 1992; Zajac, Krakowka, Herd, \& McClure, 1990) and to infection with Fasciola hepatica (Boyce, Courtney, \& Loggins, 1987). Resistance depends on both innate and adaptive immunity. Reduced establishment of Haemonchus contortus is associated with production of a rapid and greater cellular immune response and increased levels of IgA (S. Bowdridge, MacKinnon, McCann, Zajac, \& Notter, 2013; S. A. Bowdridge, Zajac, \& Notter, 2015).

The evaluation of ubiquitously expressed immune proteins and identification of genetic markers of resistance to pathogens and their regulation will help increase understanding of contributing factors to immune relaxation and PRR. Recent studies by our group have demonstrated differential regulation of galectin gene transcription and translation in periparturient cows (Asiamah et al., 2018), and goats (Ekwemalor et al., 2018). Galectins are conserved immune proteins found in many animals (Barondes, Cooper, Gitt, \& Leffler, 1994). They are responsible for intercellular and intracellular cell communication by binding cell surface glycoconjugates. They are expressed and secreted by both immune and nonimmune cells (Thiemann \& Baum, 2016). Fifteen (15) galectins have been described so far and grouped into three (3) types depending on their structure (Vasta, 2009). Many studies have been done to define the role of galectins in tissues during pregnancy (Okumu et al., 2011; Than et al., 2015; Than et al., 2012) and as regulators of immune cell homeostasis and inflammation (Breuilh et al., 2007; Rabinovich \& Toscano, 2009). They are involved in the regulation of both innate and adaptive immunity (Liu, Yang, \& Hsu, 2012).

Galectins are involved in host-parasite interactions such as adhesion of pathogens to host cells and host adaptive immunity (Shi, Xue, Su, \& Lu, 2017). Sheep galectins have been identified. Expression has been reported in tissues such as the uterus (Lewis et al., 2007), placenta (Shin, Choi, Longtine, \& Nelson, 2010), splenocytes (Ramkumar \& Podder, 2000), abomasum (French et al., 2008), lung (Dunphy et al., 2002) mammary gland (Dunphy et al., 2000) liver (Rojas et al., 2015) leukocytes (Díaz-Alvarez \& Ortega, 2017; Dunphy et al., 2000). In nematode resistant sheep galectin gene expression was associated with the immune mechanism to gastrointestinal parasites (Chitneedi, Suárez-Vega, Martínez-Valladares, Arranz, \& Gutiérrez-Gil, 2018).

Galectin expression is regulated by many factors including pathogen recognition (Knight et al., 2011; McRae et al., 2016). Galectin expression is influenced by supplementation with probiotics (Romond et al., 2009). Two strains of bifidobacteria were identified that interacted with Gal-3 (Kavanaugh, Kane, Joshi, \& Hickey, 2013). The ability of commensal microbes to interact with gal-3 may indicate an ability to exclude and displace pathogens. In parasite infections, host glycoproteins interact with parasite glycans in shaping innate and adaptive immune responses upon infection. Parasites also use their glycans to target glycan-binding protein (GBPs) within the host to promote their survival (van Kooyk, Engering, Lekkerkerker, Ludwig, \& Geijtenbeek, 2004). Secreted galectins bind serum proteins including immunoglobulins (Cederfur et al., 2008). Secreted galectins from sheep regulated apoptosis, cell proliferation and cell differentiation (Iglesias, Rabinovich, Ivanovic, Sotomayor, \& WolfensteinTodel, 1998). In light of the identified role of Galectins in the response to pathogens and immune modulation, the possible role of Galectins in periparturient immune relaxation and PRR needs definition. The objective of this study was to evaluate galectin secretion and its relationship to measures of the immune relaxation and PRR in periparturient sheep.

\section{Materials and Methods}

\subsection{Animals}

Six (6) clinically healthy adult pregnant female St. Croix ewes from the North Carolina A\&T State University Small Ruminant Research Unit were used in the study. No sheep exhibited any evidence of disease or received medications during the study period. Protocols for the handling of the animals were approved by the Institutional Animal Care and Use Committee (IACUC).

The sheep were housed indoors at night and were put out to graze on pasture during the day. They were also provided with approximately $1 \mathrm{lb} /$ feed/day of $17 \%$ pellet feed per sheep (Southern State Company). Water and trace mineral salt block was also available ad libitum.

\subsection{Experimental Design}

Six pregnant St. Croix sheep were used in the study. Samples were taken weekly for six weeks. Testing procedures were performed weekly and constituted of body weight, body condition scores, FAMACHA scores, Fecal Egg 
Count (FEC), Packed Cell Volume (PCV), white blood cell count, total plasma protein concentration, expression and secretion of galectins.

\subsection{Sample Collection}

Sheep were weighed on a chute scale in kilograms before feeding in the morning. Samples were collected -21 to +21 days relative to lambing (i.e. Day -21 , day -14 , day -7 , day +7 , day +14 and day +21 ). FAMACHA score was evaluated by the color of the conjunctival mucosa membrane (Gordon \& Whitlock, 1939). Body condition score was evaluated by physically assessing the muscling and fat over and around the vertebrae in the loin region. Blood and fecal samples were collected and evaluated once a week throughout the study. Fecal samples were collected from the rectum of ewes directly.

\subsection{Hematological Analysis}

Whole blood samples $(10 \mathrm{~mL})$ were collected from the jugular vein aseptically into vacutainer tubes containing Gel and Lithium Heparin (BD, Franklin Lakes, NJ) for serum collection, and tubes containing ethylenediaminetetraacetic acid for cell count analysis. The tubes were placed on ice immediately after collection and were transported to the laboratory. Blood samples were handled and analyzed within 2 hours of collection.

\subsubsection{Packed Cell Volume (PCV)}

The packed cell volume (PCV) an indicator of anemia was measured using an aliquot of blood with anticoagulant. Whole blood from each animal was placed into a micro-hematocrit capillary tube and centrifuged in IEC MB Micro Hematocrit centrifuge (Damon/IEC Division) for $5 \mathrm{~min}$ at 14,000 rpm. The PCV was measured using the micro-capillary reader and results were presented as percentages.

\subsubsection{Cell Viability and White Blood Cells Differential Count}

Cell Viability was assessed using the Trypan blue dye exclusion method on the TC20 cell counting instrument (BIO-RAD, Hercules, CA) as previously described by Adjei-Fremah et al., 2016. Cell counts were evaluated in duplicates, and the average was taken. Cell viability was expressed as a percentage of [(total viable and non-viable cells/total cells)] on the TC 20 cell counter (BIO-RAD., Hercules, CA). White blood cell differential counts were conducted using the Wright Staining procedure as described by Schalm et al. (1975). White blood cell differential counts were performed using a light microscope (Carolina Biological, NC) under oil immersion (X100 magnification). One hundred cells were counted for numerical representation of various cells present in the blood sample.

\subsection{Determination of $\operatorname{Ig} A$ and $\operatorname{IgE}$ Concentrations}

Coproantibodies present in the intestinal tract or fecal matter associated with immunity to enteric infections were evaluated in the fecal samples. Different concentrations of IgA and IgE were determined in fecal samples using commercially available IgA and IgE ELISA kits (Neo Scientific., Woburn, MA) for sheep. The optical density of the reaction products was quantitatively measured at an absorbance of $450 \mathrm{~nm}$ on a microplate reader (BioTek Instruments Inc., Winooski, VT). A standard curve was used to determine IgA and IgE concentration.

\subsection{Measure of Galectins -1, -3, -9 and -14 Concentration in Serum}

The concentrations of GAL 1, GAL 3, GAL 9 and GAL 14 were determined in serum. The concentration of each galectin was evaluated using commercially available enzyme-linked immunosorbent assay (ELISA) (Neo Scientific., Woburn, MA) for goat GAL (1, 3 and 9) and sheep GAL 14 according to the manufacturer's instructions.

\subsection{Measurement of Fecal Egg Count}

The modified McMaster technique (Whitlock, 1948) was used to evaluate the fecal egg count. The number of coccidia oocysts and strongyle eggs were counted in duplicate; the average was calculated and then multiplied by 50 to get the eggs per gram (EPG) of feces for each animal (Kaplan et al., 2004). Total EPG was calculated from the sum of these counts.

\subsection{Fecal Extraction and Detection of Total Microbial, Bifidobacteria spp and Lactobacillus spp DNA}

The QIAamp stool DNA isolation kit was used to isolate total microbial DNA from fecal samples to evaluate the concentration of microbial DNA. The concentration and purity of extracted microbial DNA from fecal samples was measured using the Nanodrop Spectrophotometer ND1000 (Thermo Scientific Inc., MA). DNA isolated from the fecal samples was amplified using Real time-PCR to determine the presence of total microbial DNA and relative abundance of Bifidobacteria spp and Lactobacillus spp. The GAPDH (Forward: GTCTTCACCACCATGGAG, Reverse: CTCCATGGTGGTGAAGAC) gene was used as a housekeeping gene and 
for normalizing data. Universal bacteria $16 \mathrm{~S}$ rRNA gene primers detected total microbial DNA. Primers specific for the amplification of variable regions of $16 \mathrm{~S}$ rRNA gene for Bifidobacteria spp (Forward: GAGGCAGCAGTAGGGAATCTTC, Reverse: GGCCAGTTACTACCTCTATCCTTCTTC) and Lactobacillus spp (Forward: CGCGTCYGGTGTGAAAG; Reverse: CCCCACATCCAGCATCCA) were also used. The housekeeping gene 16S Rrna (Forward: ACTCCTACGGGGAGGCAGCA; Reverse: GGACTACHVGGTWTCTAAT) was used for normalization and data analysis

\subsection{Sodium Dodecyl Sulfate-Polyacrylamide Gel Electrophoresis}

The Bicinchoninic acid assay (BCA) was used to determine the total protein concentration in serum following the manufacturer's instructions (Thermo Scientific Inc., Waltham, MA). The mini-Protein TGX Precast Protein Gels (BIO-RAD, Hercules, CA) were used to separate serum proteins. Serum $(20 \mu \mathrm{g})$ was run under reducing condition by treatment with $2 \mathrm{X}$ treatment buffer which contained 2-mercaptoethanol in a ratio of 1: 1 and boiled for 10 minutes. Protein molecular weight standards used were provided by Plus ${ }^{\mathrm{TM}}$ Protein Dual color (BIO-RAD, Hercules, CA). Protein standards and serum samples were carefully loaded into the appropriate wells and electrophoresis carried out with a current of 100volts for 45 minutes using a protein electrophoresis power supply (BIO-RAD, Hercules, CA). The gel was stained with Bio-Safe Coomassie G-250 stain, for one hour at room temperature following the manufacturer's instructions. Visualization of protein bands was done using Image $\mathrm{Lab}^{\mathrm{TM}}$ software version 5.2.1 (BIO-RAD, Hercules, CA).

\subsection{Statistical Analysis}

All data were analyzed using SAS software version 9.4 (SAS Institute, Cary, NC). Data are represented as means. For white blood cell differential cell counts and TC 20 counts, means of treatment groups were compared with one-way Analysis of variance (ANOVA). When the ANOVA showed that there were significant differences between the groups, Least significant difference (LSD) $\mathrm{P} \leq 0.05$ level was used to identify the sources of these differences. Concentrations of total serum protein and secreted galectin were determined using a standard curve. Real-time PCR data were analyzed using the Livak's method 2(- $\Delta \Delta \mathrm{Ct})$ (Livak \& Schmittgen, 2001). The housekeeping gene GAPDH was used for normalization and analysis of the relative abundance of Bifidobacteria spp and Lactobacillus spp. Week 1(day -21 relative to lambing) was used as the control.

\section{Results}

All sheep were in good health condition at the beginning and end of the study. There were no clinically significant differences found in clinical indicators, including vital signs of anemia throughout the study.

\subsection{Phenotypic Parameters}

All sheep had an initial average weight of $\geq 200 \mathrm{~kg}$ and an average body condition score of $\leq 5$ at the start of the study. Weekly Body condition score $(\mathrm{P} \leq 0.0001)$ (figure 1$)$ and body weight $(\mathrm{P} \leq 0.0054)$ (figure 2$)$ of the sheep remained constant before lambing but both decreased after lambing.

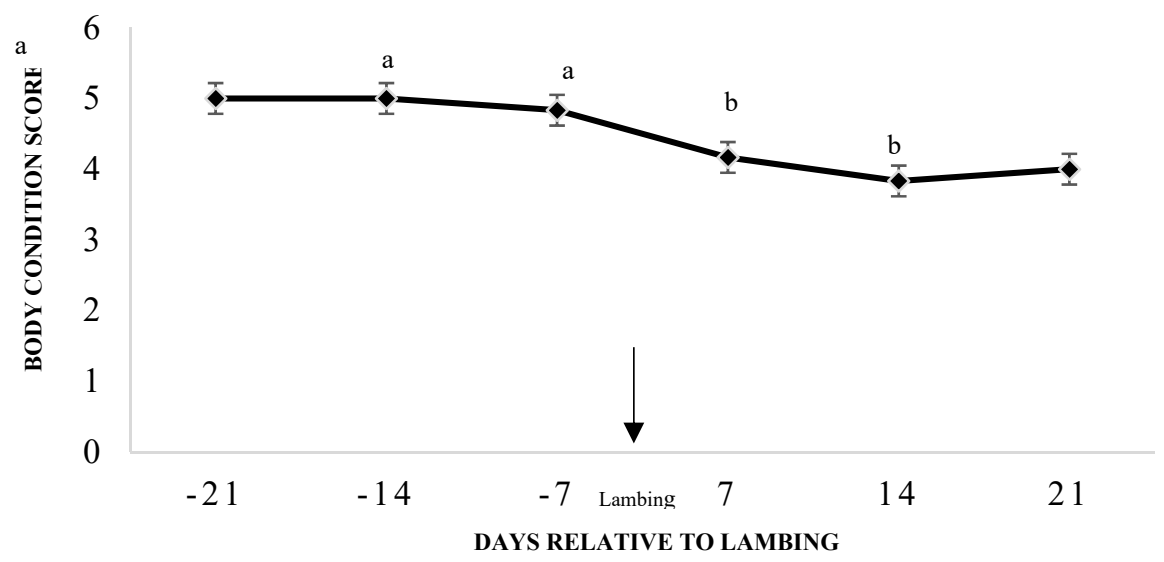

Figure 1. Average body condition score of sheep $(n=6)$ during the periparturient period. Different superscripts are significantly different $(\mathrm{p}<0.05)$. 


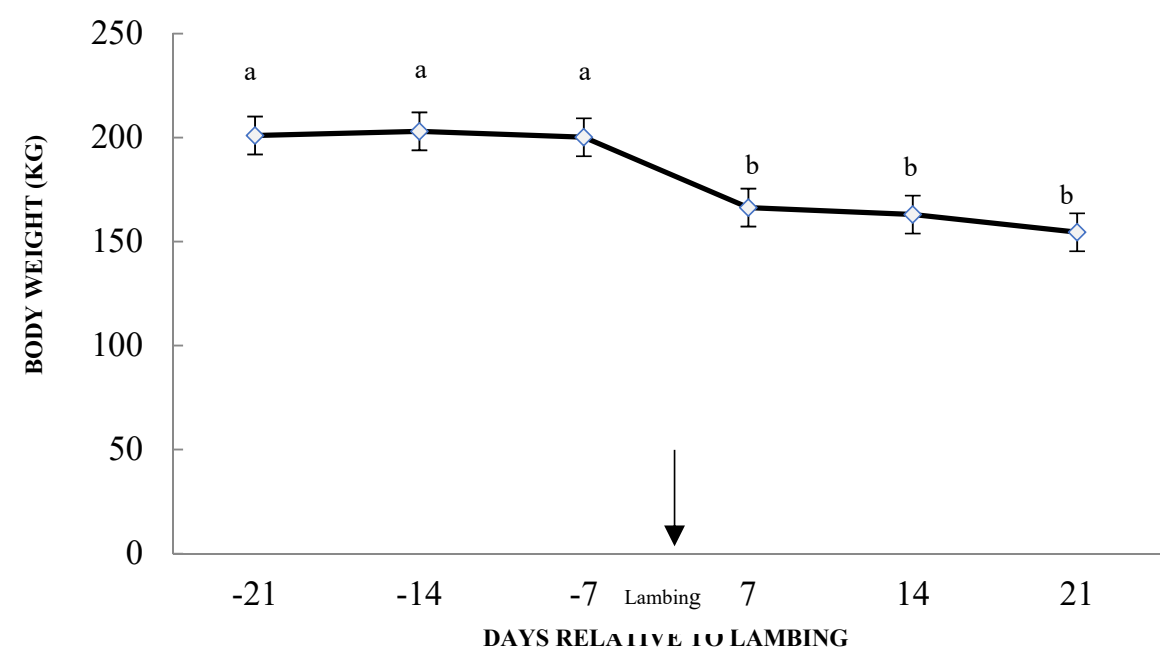

Figure 2. Mean weekly body weights of the sheep $(n=6)$ during the periparturient period. Different superscripts are significantly different $(\mathrm{p}<0.05)$

The total parasite egg count in fecal samples was low and varied during the periparturient period (figure 3 ). The total parasite egg count was between 50-100 epg. Coccidia oocytes and strongyle eggs were detected during the periparturient period. Coccidia oocytes were low before lambing (day -21, -14 and -7), however, the oocytes increased 7 days after lambing. At day 14 and 21 after lambing, the number of coccidia oocytes reduced. Strongyle eggs counted were relatively high before lambing compared to a decrease in egg count +7 days after lambing (figure 3).

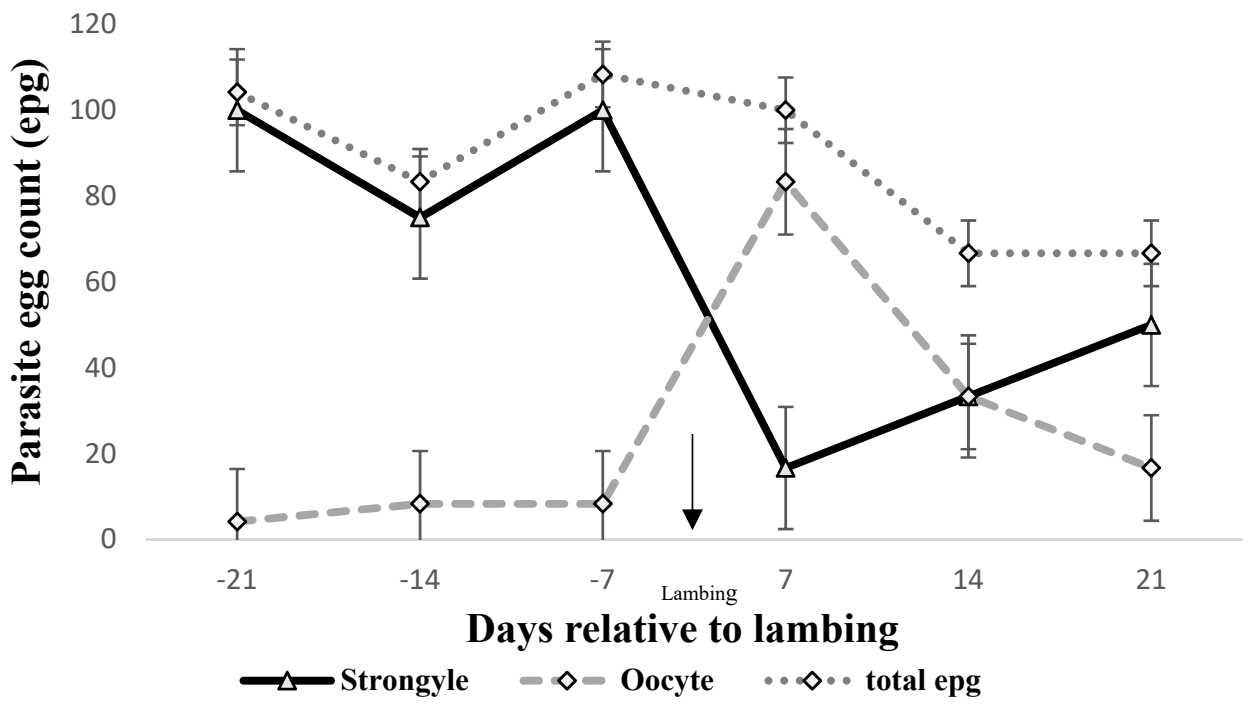

Figure 3. Mean weekly parasites egg per gram of feces during the periparturient period. The weekly mean parasite egg count was not significantly different

\subsection{Relative Abundance of Fecal Microbial DNA}

Table 3 shows the relative abundance of total microbe(16S), Bifidobacterium spp and Lactobacillus spp DNA. Bifidobacterium spp and Lactobacillus spp DNA were detected during the 6 weeks period. The mean relative abundance of Bifidobacterium spp DNA increased after lambing. Bifidobacterium spp DNA was very high on the day -14 before lambing and day 14 after lambing. Lactobacillus spp DNA reduced after day -14 and remained constantly low after lambing $(+7$ days, +14 days, +21 days $)$ through the study. 
Table 3. Relative abundance of Bifidobacterium spp and Lactobacillus spp over six (6) weeks around the periparturient period

\begin{tabular}{lllllll}
\hline \multirow{2}{*}{ Microbe } & \multicolumn{7}{l}{ Days Before } & \multicolumn{5}{l}{ Days After } \\
\cline { 2 - 7 } & -21 & -14 & -7 & 7 & 14 & 21 \\
\hline Bifidobacterium spp & 1.0 & 246.5 & 0.2 & 2.0 & 59.3 & 15.0 \\
Lactobacillus spp & 1.0 & 1.8 & 0.1 & 0.1 & 0.1 & 0.1 \\
16S & 1.0 & 1.1 & 0.4 & 0.8 & 0.3 & 1.1 \\
\hline
\end{tabular}

Day -21(3 weeks before lambing); Day -14 (2 weeks before lambing); Day -7 (1 week before lambing);

Day 7(1 week after lambing); 14 (2 weeks after lambing); 21 (3 weeks after lambing).

\subsection{Concentration of IgA and IgE Coproantibodies}

Figure 4 shows different concentrations of IgA and IgE coproantibodies in sheep fecal samples. The IgE concentration fluctuated throughout the 6 weeks study. The concentration was highest at day -7 but reduced at day 7 after lambing. The concentration IgA of coproantibodies increased weekly throughout the study.
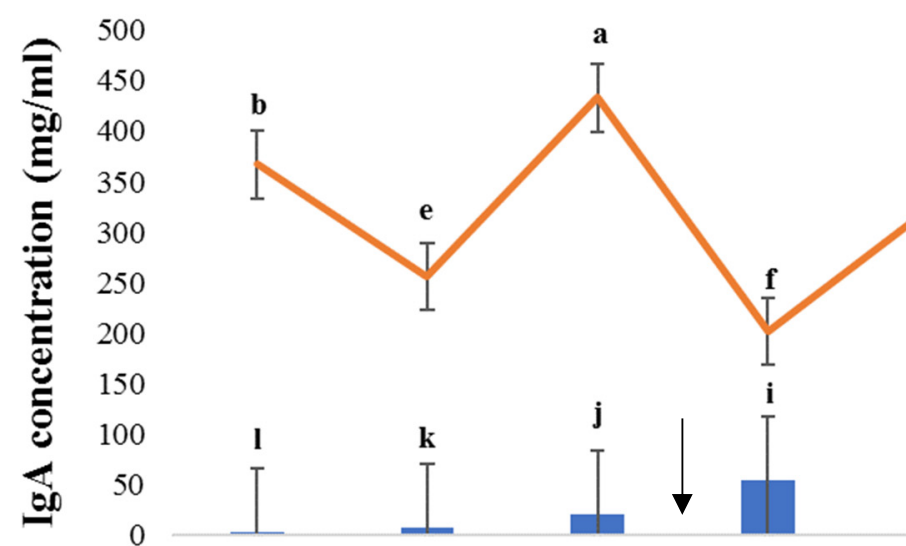

50
100
50

0
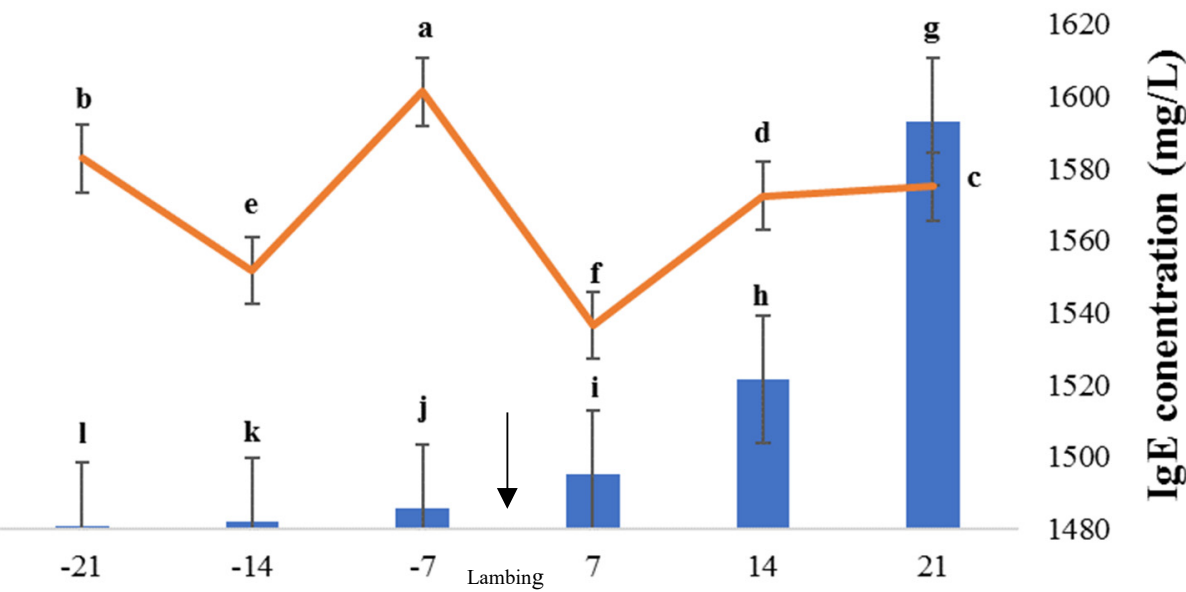

Days relative to lambing

Figure 4. Mean weekly IgA and IgE coproantibody concentration of sheep ( $\mathrm{n}=6)$ over a period of six (6) weeks during the periparturient period. Different superscripts are significantly different $(p<0.05)$

\subsection{Blood Analysis}

\subsubsection{Packed Cell Volume (PCV)}

The packed cell volume was between $34.9-39.3 \%$ before lambing and $25.4-37 \%$ after lambing. There was no significant decrease in PCV after lambing ( $\mathrm{p}>0.05$ ) (figure 5). FAMACHA score remained constant through the study (figure 5).

\subsubsection{Total and Viable Cell Count}

Both total cell and viable cell count fluctuated before lambing. Total cell count and total viable cell count decreased after lambing, day -7 , and remained constant throughout the study (figure 6).

\subsubsection{White Blood Differential Count}

The percent neutrophil count decreased at day -7 and increased after lambing. The lymphocyte percent decreased after lambing and increased at day 14. Basophil and eosinophil percent both decreased after lambing and increased on day 21. Monocyte count increased after lambing and reduced on day 14 (figure 7). 


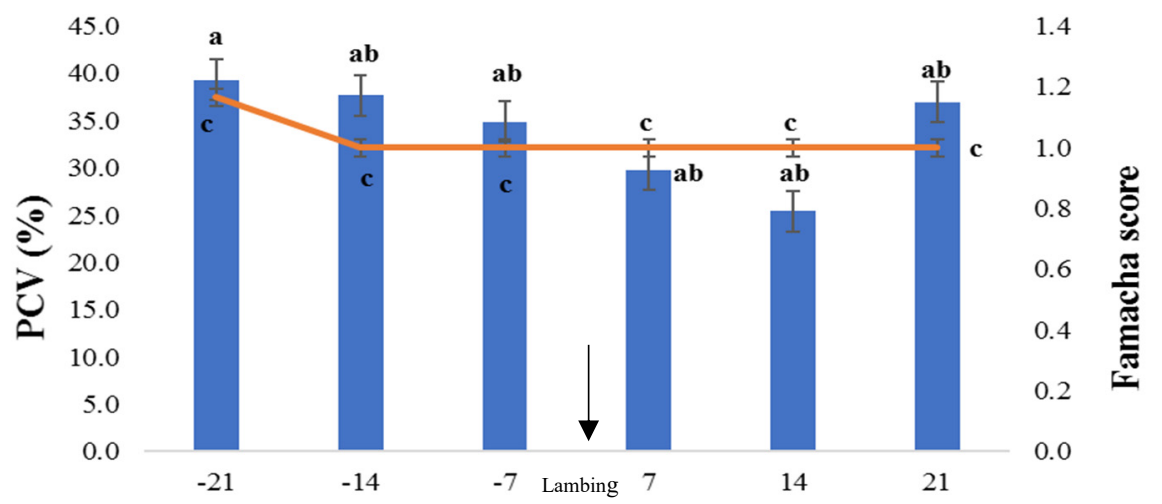

Day relative to lambing

PCV $\longrightarrow$ FS

Figure 5. Mean weekly packed cell volume (PCV) and FAMACHA score of sheep $(n=6)$ during the periparturient period. Different superscripts are significantly different $(p<0.05)$

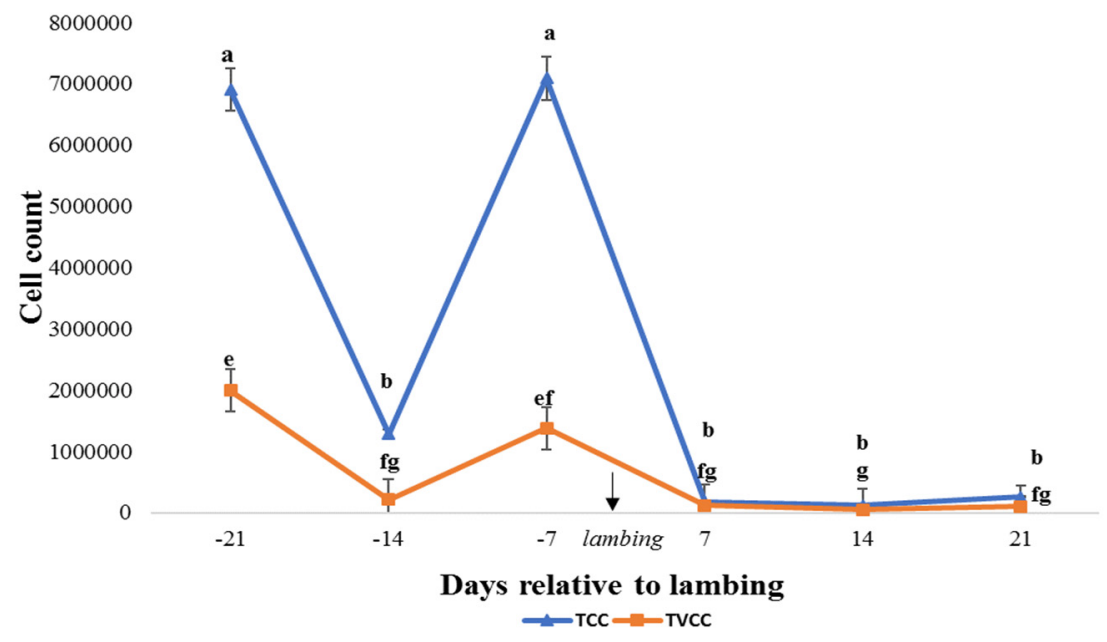

Figure 6. Mean weekly total and viable cell count in the periparturient period. Different superscripts are significantly different $(\mathrm{p}<0.05)$
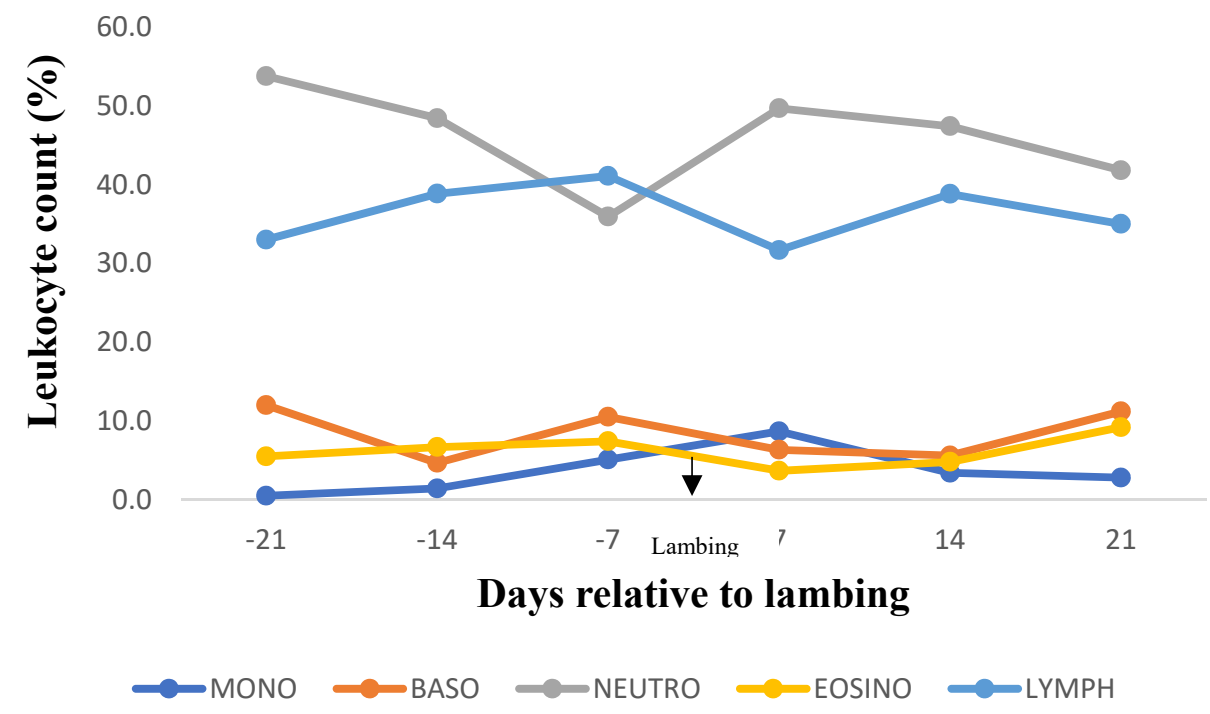

Figure 7. Mean weekly leukocyte count of sheep $(n=6)$ during the periparturient period 


\subsection{Total Protein Concentration}

Total protein concentration in sheep serum decreased significantly $(\mathrm{p}>0.05)$ at day 7 after lambing and increased through the rest of the days (Figure 8). Day +7 had the least concentration of total protein (figure 8).

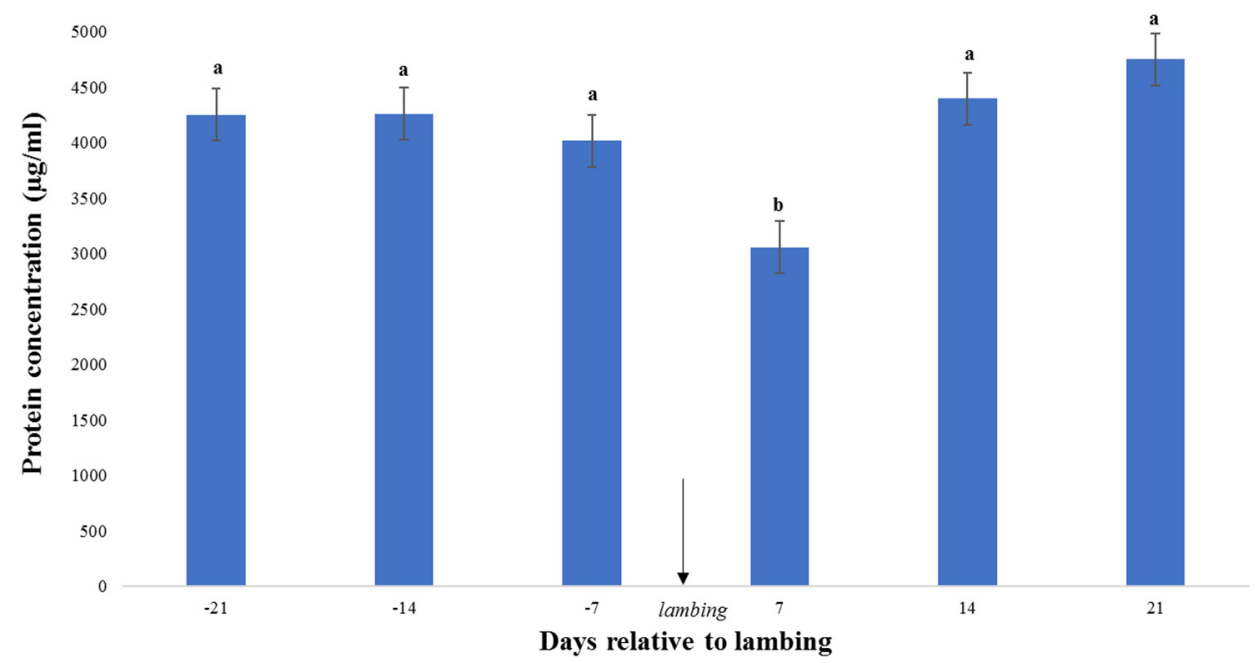

Figure 8. Mean weekly serum protein concentration during the periparturient period. Different superscripts are significantly different $(\mathrm{p}<0.05)$

3.6 Serum Protein Profile (Interactome) Sodium Dodecyl Sulfate Polyacrylamide Gel Electrophoresis (SDS$P A G E)$

The protein profile of sheep serum during the periparturient period showed different band intensity in samples (figure 9). High band intensity was observed between $75 \mathrm{KD}$ and $50 \mathrm{KD}$ in all the samples. Two bands of low molecular weight were seen in $-14,-7$ and 21 but were not seen in the other samples. Other low-intensity bands were observed. This indicates that different serum proteins were expressed over the course of the periparturient period in sheep.

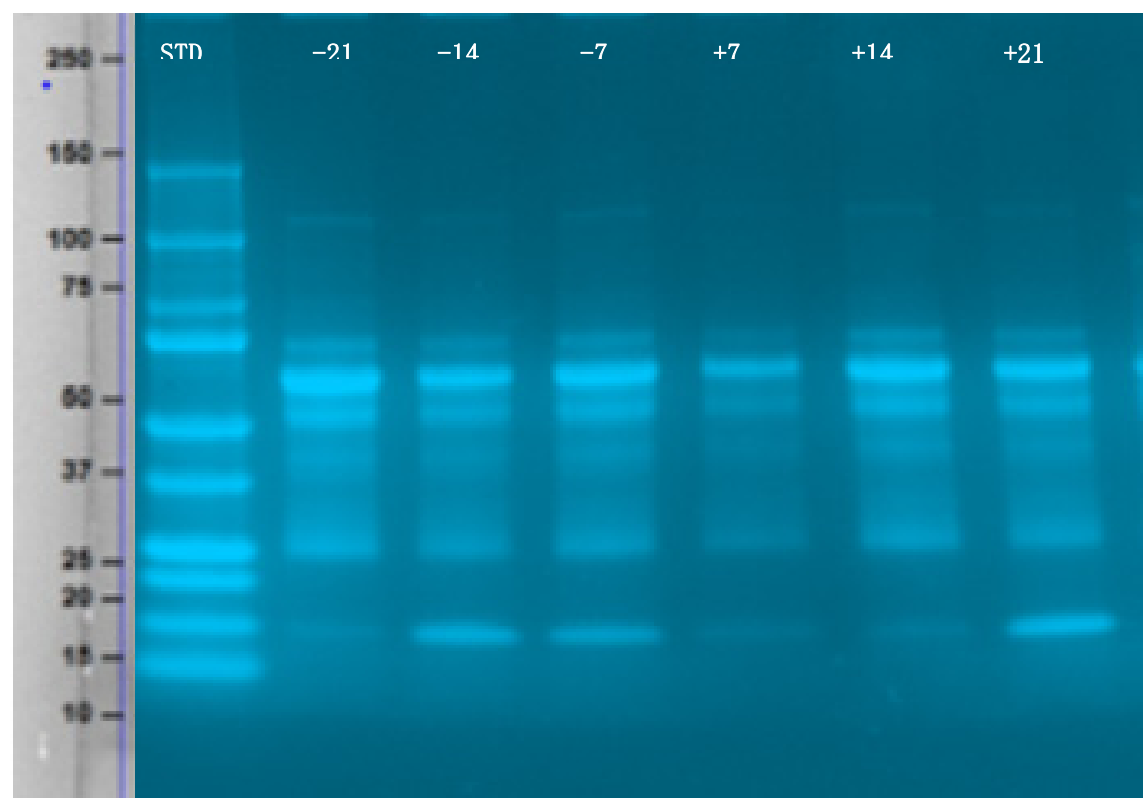

Figure 9. Sheep serum protein profile from SDS page during the periparturient period 


\subsection{Concentrations of Secreted Galectin Proteins}

Galectin 1, 3, 9, and 14 were secreted in blood at varying in concentrations. Galectin 9 and 14 were in picograms (pg) (figure 11) and galectin 1 and 3 were detected at nanograms (ng) concentration (figure 10). Galectin 1 was greater in concentration (ranging from 14.97- $32.02 \mathrm{ng} / \mathrm{ml}$ ) than galectin 3 (ranging from $1.04-1.77 \mathrm{ng} / \mathrm{ml}$ ) which was also greater than galectin 9 (ranging from $187.34-413.28 \mathrm{pg} / \mathrm{ml}$ ). Galectin 14 was the least amount measured in serum (ranging from $85.49-289.29 \mathrm{pg} / \mathrm{ml}$ ). The highest galectin 1, 3, 9 and 14 concentrations in serum were observed on day 14 after lambing. All the galectins decreased after lambing (day 7) and increased at day 14 then decreased again on day 21. Varying concentration of galectins is secreted into sheep blood during the periparturient period.

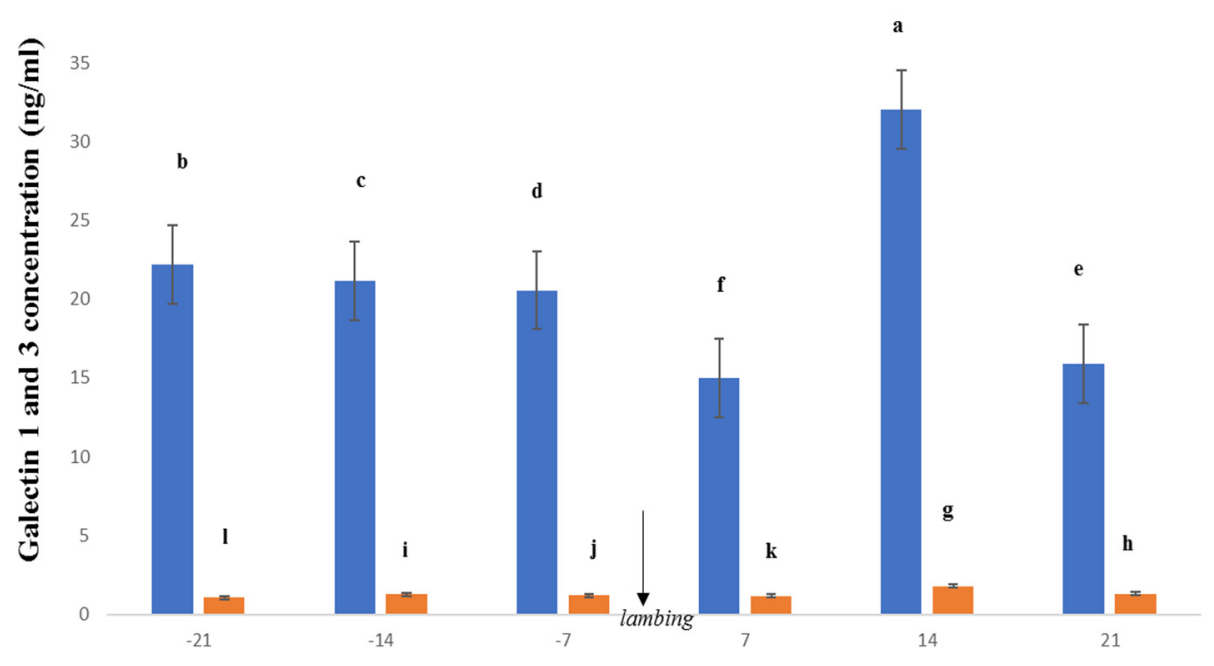

Days relative to lambing

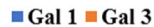

Figure 10. Concentration of galectin 1 and 3 of sheep $(n=6)$ over a period of six (6) weeks during the periparturient period. Different superscripts are significantly different $(\mathrm{p}<0.05)$

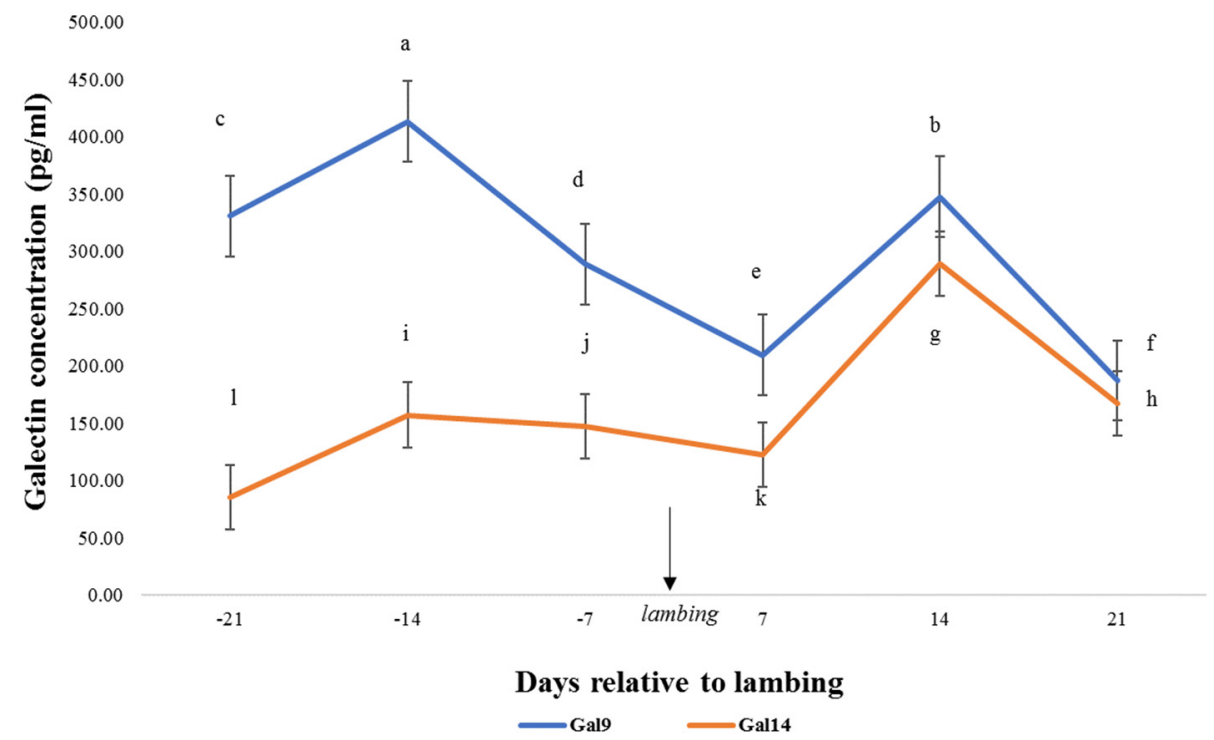

Figure 11. Concentration of galectin 9 and 14 of sheep $(n=6)$ over a period of six (6) weeks around the periparturient period. Different superscripts are significantly different $(\mathrm{p}<0.05)$ 


\subsection{Correlation with Galectin Secretion}

Secretion of galectin 1, 3, 9, and 14 was positively correlated with Bifidobacteria levels. Strongyle eggs and coccidia oocyte levels were negatively correlated with galectin 1, 3, 9, and 14 secretions (Table 7).

Table 7. Correlation table of galectin proteins, Bifidobacteria, Haemonchus spp, and coccidia

\begin{tabular}{cccc}
\hline Galectin & Bifido & Strongyle & Coccidia \\
\hline 1 & + & NA & NA \\
3 & + & - & - \\
9 & + & - & - \\
14 & + & - & - \\
\hline
\end{tabular}

$\mathrm{NA}=$ not affected; $+=$ positive correlation; $-=$ negative

Correlation; Bifido $=$ Bifidobacteria spp.

\section{Discussion}

In this study, the sheep were exposed to natural infection, they were of similar age and management. St. Croix sheep are a breed of hair sheep that are resistant to the nematode parasite Haemonchus. Haemonchus contortus is a strongyle parasite that causes anemia among other disease symptoms in sheep. Anemia due to Haemonchus infection is evaluated using changes in the PCV and FAMACHA score. Low levels of infection with strongyle and coccidia parasites, low FAMACHA scores, and high PCV were observed in this study as has previously been reported for this breed (Burke \& Miller, 2002).

The immune response pattern and the low parasite burden confirms reports that St. Croix sheep have a vigorous immune response against parasite infection (S. A. Bowdridge et al., 2015). Increases in neutrophils, lymphocytes, and eosinophils were observed in addition to changes in the concentration and pattern of serum proteins. These are indicators of both the innate and adaptive immune response to gastrointestinal infections and coincided with parasite infection levels (McRae, Stear, Good, \& Keane, 2015).

Increases in neutrophils and monocytes have been associated with the prevention of Haemonchus parasite establishment (S. A. Bowdridge et al., 2015). This was observed in this study and may be an attempt to prevent the establishment of parasites (Figure 7). Immunoglobulins $\operatorname{IgA}$ and $\operatorname{IgE}$ are associated provide immunity against different parasite infections (Fitzsimmons, Falcone, \& Dunne, 2014; Shaw, Morris, \& Wheeler, 2013) in the gut. During the periparturient rise in fecal egg count sheep, IgA is secreted (Jeffcoate et al., 1992). Coproantibodies are antibodies in intestinal fluids or in feces (Burrows, Elliott, \& Havens, 1947). They are good indicators of the local immune response in the gut (Bretschneider, Berberov, \& Moxley, 2007; de Vos \& Dick, 1991).

Coproantibodies studies have been done in mice (de Vos \& Dick, 1991) and human (Coulson, Grimwood, Hudson, Barnes, \& Bishop, 1992; Nunez, Costantino, \& Venturiello, 2006). Both IgA and IgE coproantibodies were detected in feces from periparturient St. Croix ewes in varying concentrations (Figure 4). The level of IgA increased with increased levelss of parasite egg lvels in feces as reported by Mackinnon et al., (MacKinnon, Michels, \& Buckley, 2015). Both IgA and IgE may have affected parasite egg count since there was a negative correlation. Chevrotiere et al., (de la Chevrotière, Bambou, Arquet, Jacquiet, \& Mandonnet, 2012) reported that serum IgA positively correlated with Haemonchus parasite while a negative correlation was observed with $\operatorname{IgE}$ in goat study. However, a negative correlation was observed between IgA and strongyle eggs while IgE had a positive correlation with parasite eggs in the present study. A negative correlation was observed between IgE and coccidia oocytes. This may indicate difference in gut immune response and peripheral blood.

\subsection{Protein Profiling}

The observed variation in total protein concentration and pattern is similar to reports in proteomics studies in periparturient sheep (Nace et al., 2014). Distinct patterns of expression may have reflected a response to different stages in the parasites life cycle and the immune response to diverse pathogens as both nematode and protozoan infections were observed (Figure 9). Protein bands that changed in abundance and level may serve as biomarkers of the immune response and need further characterization (Bendixen, Danielsen, Hollung, Gianazza, \& Miller, 2011). 
Studies on galectins have shown that galectins play an important role in the immune response during the periparturient period and during an infection. We have recently reported changes in the concentration of galectins during the periparturient period in dairy cattle [17].

Increased concentrations of Galectin 1, 3, 9, and 14 were secreted in blood at varying in concentrations. Galectin 9 and 14 were in picograms (pg) (figure 15) and galectin 1 and 3 were detected at nanograms (ng) concentration (figure 14). Galectin 1 was greater in concentration (ranging from 14.97- $32.02 \mathrm{ng} / \mathrm{ml}$ ) than galectin 3 (ranging from $1.04-1.77 \mathrm{ng} / \mathrm{ml}$ ) which was also greater than galectin 9 (ranging from $187.34-413.28 \mathrm{pg} / \mathrm{ml}$ ). Galectin 14 was the least amount measured in serum (ranging from $85.49-289.29 \mathrm{pg} / \mathrm{ml}$ ). The highest galectin 1, 3, 9 and 14 concentrations in serum were observed on day 14 after lambing. All the galectins decreased after lambing (day 7 ) and increased at day 14 then decreased again on day 21 .

Varying concentration of galectins are secreted into sheep blood during the periparturient period. The functional implications of this variation should be explored. All the galectins decreased after lambing (day 7) and increased at day 14 then decreased again on day 21. This is similar to what has been reported in cows (Asiamah et al., 2018).

Studies have shown that probiotic bacteria such as Bifido bacteria may limit the availability of Galectins to bind pathogens in the gut and potentially play a role in colonization resistance and host infection (Kavanaugh et al., 2013) and modulation of Galectin gene expression in blood (Romond et al., 2009). Secretion of galectin 1, 3, 9, and 14 was positively correlated with Bifidobacteria levels. The observed correlation with epg and gut health may have implications for the immune response to Gastro parasites in cattle and other ruminants. The gastrointestinal tract is colonized by a diverse array of microflora which may be detrimental or beneficial to the host. Probiotics are beneficial microbes that reside in or are introduced into the host to improve gut health and aid in efficient digestion. Probiotics have been proven to stimulate immunity. They stimulate gene expression in cow (Adjei-Fremah et al., 2018), goat (Ekwemalor, Asiamah, Osei, Ismail, \& Worku, 2017; Ekwemalor, Asiamah, \& Worku, 2016) and sheep (Pérez-Sánchez et al., 2011). Vlková et al., (Vlková, Grmanová, Rada, Homutová, \& Dubná, 2009) studied Bifidobacteria and Lactobacillus in sheep as potential probiotics. Bifidobacteria and Lactobacillus bacteria have been found in sheep fecal samples and used as probiotics for improved production and have also been used to monitor food safety for mutton and other products (Delcenserie et al., 2008). Both organisms were present in St. Croix sheep and their abundance varied during the periparturient period with the lowest concentrations of Bifidobacteria and Lactobacillus specific DNA being detected seven days before and after lambing. These shifts may be associated with metabolic adaptation to pregnancy (Gohir et al., 2015). The presence of Bifidobacteria in the gut has also been associated with a reduction in galectin gene expression in the blood and other organs (Romond et al., 2009). In this study, both Bifidobacteria and Lactobacillus DNA had a positive correlation with secreted galectins. Commensal strains of bifidobacteria have been shown to interact strongly with gal-3 (Kavanaugh et al., 2013) and Galectin 9 was enhanced by some species of Bifidobacteria (de Kivit et al., 2012) in mice and humans.

Research by Souza et al., (Souza et al., 2015) reported a negative correlation between Haemonchus parasite burden and galectin 14 in sheep. A similar observation was made in the correlation study, strongyle eggs were negatively correlated with all the secreted galectins. The periparturient rise in parasite egg count for both Haemonchus and coccidia occurred at different days during the periparturient period. Fecal egg counts for both parasites were negatively correlated with secreted galectins. Previous research has also reported galectin responses to different parasites are different (Haemonchus contortus and Fasciola hepatica) (blood (Alvarez et al., 2015). In this study, the galectin response relative to egg count from both parasites was different. Motran et al., (Motran, Molinder, Liu, Poirier, \& Miceli, 2008) showed that galectin 1 affects Th1 and Th2 differently. Th2 has been associated with Haemonchus infection in ruminants and the Th1 response is associated with coccidia infection. Understanding how Galectins in blood contribute to disease susceptibility during the peripartum period is essential to sustainable animal production More studies are need on how secreted Galectins may contribute to the observed biasing toward a Th1-type immune response increased susceptibility to gastrointestinal nematodes in sheep (Beasley et al., 2010).

\section{Conclusion}

Galectins are differentially secreted in sheep blood. Galectin secretion changes during periparturient period. Coccidia and Nematode pathogens and commensal organisms may have differential effects on galectin secretion. This first insight into a possible role of secreted galectins in periparturient immune relaxation and PRR improves the understanding of the immune response, presents Galectin secretion profiles as biomarkers with diagnostic potential. and informs development of management programs and therapeutics. 


\section{Funding}

This research was funded by U.S. Department of Agriculture -National Institute of Food and Agriculture Evans-Allen grant [grant number NC.X-300-5-16-120-1], Improving resistance and resilience: The role of Galectins in peripaturient ruminants

\section{Acknowledgement}

The authors are grateful for the support of Dr. Hamid Ismail and Mr. Gary (North Carolina A\&T State University, small ruminant farm) during sample collection.

\section{References}

Adjei-Fremah, S., Ekwemalor, K., Asiamah, E. K., Ismail, H., Ibrahim, S., \& Worku, M. (2018). Effect of probiotic supplementation on growth and global gene expression in dairy cows. Journal of Applied Animal Research, 46(1), 257-263.

Alvarez, L. H., Feliciano, D. N., González, J. E. H., de Oliveira Soares, R., Gomes, D. E. B., \& Pascutti, P. G. (2015). Insights into the interactions of Fasciola hepatica cathepsin L3 with a substrate and potential novel inhibitors through in silico approaches. PLoS neglected tropical diseases, 9(5), e0003759.

Asiamah, E., Adjei-Fremah, S., Ekwemalor, K., Sordillo, L., \& Worku, M. (2018). Parity and Periparturient Period Affects Galectin Gene Expression in Holstein Cow Blood. Journal of Applied Biotechnology, 6(2), 20. doi: https://doi.org/10.5296/jab.v6i2.13017

Barondes, S. H., Cooper, D. N., Gitt, M. A., \& Leffler, H. (1994). Galectins. Structure and function of a large family of animal lectins. Journal of Biological Chemistry, 269, 20807-20807.

Beasley, A., Kahn, L., \& Windon, R. (2010). The periparturient relaxation of immunity in Merino ewes infected with Trichostrongylus colubriformis: parasitological and immunological responses. Veterinary Parasitology, 168(1-2), 60-70.

Bendixen, E., Danielsen, M., Hollung, K., Gianazza, E., \& Miller, I. (2011). Farm animal proteomics-a review. Journal of proteomics, 74(3), 282-293.

Bishop, S., \& Morris, C. (2007). Genetics of disease resistance in sheep and goats. Small ruminant research, 70(1), 48-59.

Bowdridge, S., MacKinnon, K., McCann, J. C., Zajac, A. M., \& Notter, D. R. (2013). Hair-type sheep generate an accelerated and longer-lived humoral immune response to Haemonchus contortus infection. Veterinary Parasitology, 196(1-2), 172-178.

Bowdridge, S. A., Zajac, A. M., \& Notter, D. R. (2015). St. Croix sheep produce a rapid and greater cellular immune response contributing to reduced establishment of Haemonchus contortus. Veterinary Parasitology, 208(3-4), 204-210.

Boyce, W., Courtney, C., \& Loggins, P. (1987). Resistance to experimental infection with Fasciola hepatica in exotic and domestic breeds of sheep. International journal for parasitology, 17(7), 1233-1237.

Bretschneider, G., Berberov, E., \& Moxley, R. A. (2007). Isotype-specific antibody responses against Escherichia coli O157: H7 locus of enterocyte effacement proteins in adult beef cattle following experimental infection. Veterinary immunology and immunopathology, 118(3-4), 229-238.

Breuilh, L., Vanhoutte, F., Fontaine, J., van Stijn, C. M., Tillie-Leblond, I., Capron, M., . . Gosset, P. (2007). Galectin-3 modulates immune and inflammatory responses during helminthic infection: impact of galectin-3 deficiency on the functions of dendritic cells. Infection and immunity, 75(11), 5148-5157.

Burke, J., \& Miller, J. (2002). Relative resistance of Dorper crossbred ewes to gastrointestinal nematode infection compared with St. Croix and Katahdin ewes in the southeastern United States. Veterinary Parasitology, 109(3-4), 265-275.

Burrows, W., Elliott, M. E., \& Havens, I. (1947). Studies on immunity to Asiatic cholera: IV. The excretion of coproantibody in experimental enteric cholera in the guinea pig. The Journal of infectious diseases, 81(3), 261-281.

Cederfur, C., Salomonsson, E., Nilsson, J., Halim, A., Öberg, C. T., Larson, G., . . Leffler, H. (2008). Different affinity of galectins for human serum glycoproteins: galectin-3 binds many protease inhibitors and acute phase proteins. Glycobiology, 18(5), 384-394. 
Chitneedi, P. K., Suárez-Vega, A., Martínez-Valladares, M., Arranz, J. J., \& Gutiérrez-Gil, B. (2018). Exploring the mechanisms of resistance to Teladorsagia circumcincta infection in sheep through transcriptome analysis of abomasal mucosa and abomasal lymph nodes. Veterinary research, 49(1), 39.

Coulson, B. S., Grimwood, K., Hudson, I., Barnes, G., \& Bishop, R. (1992). Role of coproantibody in clinical protection of children during reinfection with rotavirus. Journal of clinical microbiology, 30(7), 1678-1684.

Courtney, C., Parker, C., McClure, K., \& Herd, R. (1985). Resistance of nonlambing exotic and domestic ewes to naturally acquired gastrointestinal nematodes. International journal for parasitology, 15(3), 239-243.

de Kivit, S., Saeland, E., Kraneveld, A. D., van de Kant, H. J., Schouten, B., van Esch, B. C., . . Knippels, L. (2012). Galectin-9 induced by dietary synbiotics is involved in suppression of allergic symptoms in mice and humans. Allergy, 67(3), 343-352.

de la Chevrotière, C., Bambou, J.-C., Arquet, R., Jacquiet, P., \& Mandonnet, N. (2012). Genetic analysis of the potential role of IgA and IgE responses against Haemonchus contortus in parasite resistance of Creole goats. Veterinary Parasitology, 186(3-4), 337-343.

de Vos, T., \& Dick, T. A. (1991). A rapid method to determine the isotype and specificity of coproantibodies in mice infected with Trichinella or fed cholera toxin. Journal of immunological methods, 141(2), 285-288.

Delcenserie, V., Martel, D., Lamoureux, M., Amiot, J., Boutin, Y., \& Roy, D. (2008). Immunomodulatory effects of probiotics in the intestinal tract. Current issues in molecular biology, 10(1/2), 37.

Díaz-Alvarez, L., \& Ortega, E. (2017). The many roles of galectin-3, a multifaceted molecule, in innate immune responses against pathogens. Mediators of inflammation, 2017.

Dunphy, J. L., Balic, A., Barcham, G. J., Horvath, A. J., Nash, A. D., \& Meeusen, E. N. (2000). Isolation and characterization of a novel inducible mammalian galectin. Journal of Biological Chemistry, 275(41), 32106-32113.

Dunphy, J. L., Barcham, G. J., Bischof, R. J., Young, A. R., Nash, A., \& Meeusen, E. N. (2002). Isolation and characterization of a novel eosinophil-specific galectin released into the lungs in response to allergen challenge. Journal of Biological Chemistry, 277(17), 14916-14924.

Ekwemalor, K., Adjei-Fremah, S., Asiamah, E., \& Worku, M. (2017). Molecular Genetics and Genome Biology of Goats Goat Science: IntechOpen.

Ekwemalor, K., Asiamah, E., Eluka-Okoludoh, E., Mulakala, B., Adjei-Fremah, S., \& Worku, M. (2018). CPQ Microbiology (2018) 1: 5 Research Article. Microbiology, 1(5), 01-06.

Ekwemalor, K., Asiamah, E., Osei, B., Ismail, H., \& Worku, M. (2017). Evaluation of the Effect of Probiotic Administration on Gene Expression in Goat Blood. Journal of Molecular Biology Research, 7(1), 88.

Ekwemalor, K., Asiamah, E., \& Worku, M. (2016). Effect of a mushroom (Coriolus versicolor) based probiotic on the expression of toll-like receptors and signal transduction in goat neutrophils. Journal of Molecular Biology Research, 6(1), 71.

Fitzsimmons, C. M., Falcone, F. H., \& Dunne, D. W. (2014). Helminth allergens, parasite-specific IgE, and its protective role in human immunity. Frontiers in immunology, 5, 61.

French, A. T., Knight, P. A., Smith, W. D., Brown, J. K., Craig, N. M., Pate, J. A., . . Pemberton, A. D. (2008). Up-regulation of intelectin in sheep after infection with Teladorsagia circumcincta. International journal for parasitology, 38(3-4), 467-475.

Gamble, H. R., \& Zajac, A. M. (1992). Resistance of St. Croix lambs to Haemonchuscontortus in experimentally and naturally acquired infections. Veterinary Parasitology, 41(3-4), 211-225.

Gohir, W., Whelan, F. J., Surette, M. G., Moore, C., Schertzer, J. D., \& Sloboda, D. M. (2015). Pregnancy-related changes in the maternal gut microbiota are dependent upon the mother's periconceptional diet. Gut Microbes, 6(5), 310-320.

Goldberg, V., Ciappesoni, G., \& Aguilar, I. (2012). Genetic parameters for nematode resistance in periparturient ewes and post-weaning lambs in Uruguayan Merino sheep. Livestock Science, 147(1-3), 181-187.

Gordon, H. M., \& Whitlock, H. (1939). A new technique for counting nematode eggs in sheep faeces. Journal of the council for Scientific and Industrial Research, 12(1), 50-52. 
Houdijk, J., Kyriazakis, I., Jackson, F., Huntley, J., \& Coop, R. (2000). Can an increased intake of metabolizable protein affect the periparturient relaxation in immunity against Teladorsagia circumcincta in sheep? Veterinary Parasitology, 91(1-2), 43-62.

Iglesias, M. M., Rabinovich, G. A., Ivanovic, V., Sotomayor, C., \& Wolfenstein-Todel, C. (1998). Galectin-1 from ovine placenta: Amino-acid sequence, physicochemical properties and implications in T-cell death. European journal of biochemistry, 252(3), 400-407.

Jeffcoate, I., Wedrychowicz, H., Fishwick, G., Dunlop, E., Duncan, J., \& Holmes, P. (1992). Pathophysiology of the periparturient egg rise in sheep: a possible role for IgA. Research in veterinary science, 53(2), 212-218.

Kavanaugh, D., Kane, M., Joshi, L., \& Hickey, R. M. (2013). Detection of galectin-3 interaction with commensal bacteria. Applied and environmental microbiology, AEM. 03694-03612.

Knight, P. A., Griffith, S. E., Pemberton, A. D., Pate, J. M., Guarneri, L., Anderson, K., . . Fell, M. (2011). Novel gene expression responses in the ovine abomasal mucosa to infection with the gastric nematode Teladorsagia circumcincta. Veterinary research, 42(1), 78.

Lewis, S. K., Farmer, J. L., Burghardt, R. C., Newton, G. R., Johnson, G. A., Adelson, D. L., . . Spencer, T. E. (2007). Galectin 15 (LGALS15): a gene uniquely expressed in the uteri of sheep and goats that functions in trophoblast attachment. Biology of reproduction, 77(6), 1027-1036.

Liu, F. T., Yang, R. Y., \& Hsu, D. K. (2012). Galectins in acute and chronic inflammation. Annals of the New York Academy of Sciences, 1253(1), 80-91.

Livak, K. J., \& Schmittgen, T. D. (2001). Analysis of relative gene expression data using real-time quantitative PCR and the 2- $\Delta \Delta \mathrm{CT}$ method. methods, 25(4), 402-408.

MacKinnon, R. A., Michels, R., \& Buckley, P. J. (2015). The psychiatric interview in clinical practice: American Psychiatric Pub.

McRae, K. M., Good, B., Hanrahan, J. P., McCabe, M. S., Cormican, P., Sweeney, T., . . Keane, O. M. (2016). Transcriptional profiling of the ovine abomasal lymph node reveals a role for timing of the immune response in gastrointestinal nematode resistance. Veterinary Parasitology, 224, 96-108.

McRae, K. M., Stear, M. J., Good, B., \& Keane, O. M. (2015). The host immune response to gastrointestinal nematode infection in sheep. Parasite immunology, 37(12), 605-613.

Motran, C. C., Molinder, K. M., Liu, S. D., Poirier, F., \& Miceli, M. C. (2008). Galectin-1 functions as a Th2 cytokine that selectively induces Th1 apoptosis and promotes Th2 function. European journal of immunology, 38(11), 3015-3027.

Nace, E. L., Nickerson, S., Kautz, F., Breidling, S., Wochele, D., Ely, L., \& Hurley, D. (2014). Modulation of innate immune function and phenotype in bred dairy heifers during the periparturient period induced by feeding an immunostimulant for 60 days prior to delivery. Veterinary immunology and immunopathology, 161(3-4), 240-250.

Notter, D., Burke, J., Miller, J., \& Morgan, J. (2017). Factors affecting fecal egg counts in periparturient Katahdin ewes and their lambs. Journal of animal science, 95(1), 103-112.

Nunez, G., Costantino, S., \& Venturiello, S. (2006). Detection of coproantibodies and faecal immune complexes in human trichinellosis. Parasitology, 134(5), 723-727.

Okumu, L. A., Fair, T., Szekeres-Bartho, J., O'Doherty, A. M., Crowe, M. A., Roche, J. F., . . Forde, N. (2011). Endometrial expression of progesterone-induced blocking factor and galectins-1,-3,-9, and-3 binding protein in the luteal phase and early pregnancy in cattle. Physiological genomics, 43(14), 903-910.

Pérez-Sánchez, T., Balcázar, J. L., Merrifield, D. L., Carnevali, O., Gioacchini, G., de Blas, I., \& Ruiz-Zarzuela, I. (2011). Expression of immune-related genes in rainbow trout (Oncorhynchus mykiss) induced by probiotic bacteria during Lactococcus garvieae infection. Fish \& shellfish immunology, 31(2), 196-201.

Piedrafita, D., Raadsma, H. W., Gonzalez, J., \& Meeusen, E. (2010). Increased production through parasite control: can ancient breeds of sheep teach us new lessons? Trends in parasitology, 26(12), 568-573.

Rabinovich, G. A., \& Toscano, M. A. (2009). Turning'sweet'on immunity: galectin-glycan interactions in immune tolerance and inflammation. Nature Reviews Immunology, 9(5), 338.

Ramkumar, R., \& Podder, S. K. (2000). Elucidation of the mechanism of interaction of sheep spleen galectin-1 with splenocytes and its role in cell-matrix adhesion. Journal of Molecular Recognition, 13(5), 299-309. 
Rocha, R., Bricarello, P., Silva, M., Houdijk, J., Almeida, F., Cardia, D., \& Amarante, A. F. T. d. (2011). Influence of protein supplementation during late pregnancy and lactation on the resistance of Santa Ines and Ile de France ewes to Haemonchus contortus. Veterinary Parasitology, 181(2-4), 229-238.

Rojas, C. A. A., Ansell, B. R., Hall, R. S., Gasser, R. B., Young, N. D., Jex, A. R., \& Scheerlinck, J.-P. Y. (2015). Transcriptional analysis identifies key genes involved in metabolism, fibrosis/tissue repair and the immune response against Fasciola hepatica in sheep liver. Parasites \& vectors, 8(1), 124.

Romond, M.-B., Mullié, C., Colavizza, M., Revillion, F., Peyrat, J.-P., \& Izard, D. (2009). Intestinal colonization with bifidobacteria affects the expression of galectins in extraintestinal organs. FEMS Immunology \& Medical Microbiology, 55(1), 85-92.

Shaw, R., Morris, C., \& Wheeler, M. (2013). Genetic and phenotypic relationships between carbohydrate larval antigen (CarLA) IgA, parasite resistance and productivity in serial samples taken from lambs after weaning. International journal for parasitology, 43(8), 661-667.

Shi, W., Xue, C., Su, X.-Z., \& Lu, F. (2017). The roles of galectins in parasitic infections. Acta tropica.

Shin, J. S., Choi, M. Y., Longtine, M. S., \& Nelson, D. M. (2010). Vitamin D effects on pregnancy and the placenta. Placenta, 31(12), 1027-1034.

Souza, B. M. P. d. S., Lambert, S. M., Nishi, S. M., Benavides, M. V., Berne, M. E. A., Madruga, C. R., \& Almeida, M. A. O. d. (2015). Galectins and collectinis expression are increased in Haemonchus contortus-infected corriedale sheep. Revista Brasileira de Parasitologia Veterinária, 24(3), 317-323.

Than, N. G., Romero, R., Balogh, A., Karpati, E., Mastrolia, S. A., Staretz-Chacham, O., . . Kim, C. J. (2015). Galectins: Double-edged swords in the cross-roads of pregnancy complications and female reproductive tract inflammation and neoplasia. Journal of pathology and translational medicine, 49(3), 181.

Than, N. G., Romero, R., Kim, C. J., McGowen, M. R., Papp, Z., \& Wildman, D. E. (2012). Galectins: guardians of eutherian pregnancy at the maternal-fetal interface. Trends in Endocrinology \& Metabolism, 23(1), 23-31.

Thiemann, S., \& Baum, L. G. (2016). Galectins and immune responses - just how do they do those things they do? Annual review of immunology, 34, 243-264.

van Kooyk, Y., Engering, A., Lekkerkerker, A. N., Ludwig, I. S., \& Geijtenbeek, T. B. (2004). Pathogens use carbohydrates to escape immunity induced by dendritic cells. Current opinion in immunology, 16(4), 488-493.

Vasta, G. R. (2009). Roles of galectins in infection. Nature Reviews Microbiology, 7(6), 424.

Vlková, E., Grmanová, M., Rada, V., Homutová, I., \& Dubná, S. (2009). Selection of probiotic bifidobacteria for lambs. Czech J. Anim. Sci, 54, 552-565.

Zajac, A., Krakowka, S., Herd, R., \& McClure, K. (1990). Experimental Haemonchus contortus infection in three breeds of sheep. Veterinary Parasitology, 36(3-4), 221-235.

\section{Copyrights}

Copyright for this article is retained by the author(s), with first publication rights granted to the journal.

This is an open-access article distributed under the terms and conditions of the Creative Commons Attribution license (http://creativecommons.org/licenses/by/4.0/). 